\title{
A general topoisomerase I-dependent transcriptional repression in the stationary phase in yeast
}

\author{
Mordechai Choder ${ }^{1}$ \\ Department of Biochemistry and Molecular Biology, Harvard University, Cambridge, Massachusetts 02138 USA
}

This paper shows that in the yeast Saccharomyces cerevisiae the levels of most mRNAs decrease, in a temporally orchestrated manner, as cells approach and enter the stationary phase. The decreased level of mRNAs is primarily due to transcriptional repression because the overall rate of in vivo transcription by RNA polymerase II is similarly reduced in the stationary phase. The reduction in mRNA levels and the general transcriptional repression are both dependent on topoisomerase I (encoded by TOP1). Specifically, these two processes are much slower in top1 mutants, as their mRNA levels and transcriptional rate remain unchanged for a longer period of time in the stationary phase before they start to decrease. In contrast, the mRNA levels in the stationary phase are not affected by perturbation of topoisomerase II activity. TOP1-dependent repression operates even on $H S P 26$ and $S S A 3$, which have been shown previously to be transcriptionally induced in early stationary phase. Thus, their mRNA levels are high upon the entry of the cells into the stationary phase but gradually decrease, by a TOP1-dependent mechanism, later in the stationary phase. A minor population of mRNAs is not subjected to the TOP1-dependent regulation, as their levels do not change in stationary phase. The possible role of topoisomerase $I$ in the general transcriptional repression is discussed.

[Key Words: Yeast; stationary phase; transcription; topoisomerases]

Received July 15, 1991; revised version accepted September 23, 1991.

In nature, unicellular organisms exist largely in nonoptimal conditions (e.g., starvation), many of which are analogous to the stationary phase, characteristic of cells that exhaust critical nutrients while growing in the test tube and stop dividing. Whereas the cell-cycle-dependent programming of gene expression has been subjected to intensive studies in recent years, little is known about the mechanism governing gene expression during the stationary phase.

When the yeast Saccharomyces cerevisiae cells are cultured on a fermentable carbohydrate, they exhibit two distinct growth phases followed by the stationary phase (for review, see Kappeli 1986). In the first phase, cells grow fast and their mass is increased logarithmically (log phase). Cells meet their energy requirements during this phase primarily by fermentation (Lagunas 1986). The second growth phase is initiated when cells exhaust most of the fermentable carbon source, undergo major physiological and morphological changes, and begin to grow at a much slower rate. The shift between these two growth phases is called the "diauxic shift." At the slow-growth phase, glycolysis is repressed and cells use the respiratory pathway as their main source of ATP, with the products of fermentation being their primary

'Present address: Whitehead Institute for Biomedical Research, Cambridge, Massachusetts 02142 USA. carbon sources (for review, see Pringle and Hartwell 1981). In addition to the metabolic changes, the cell wall becomes more resistant to degradative enzymes (Paris and Pringle 1983), the percentage of budded cells start to decrease (Boucherie 1985), catabolite repression is relieved, and storage carbohydrates begin to accumulate (for review, see Entian 1986). SSA3, a member of the yeast multigene $H S P 70$ family, is transcriptionally activated following the diauxic shift (Boorstein and Craig 1990a). A cis-acting regulatory element in the promoter of $S S A 3$, distinct from the heat shock upstream activating element located nearby, governs the postdiauxic shift transcriptional induction (Boorstein and Craig 1990a). At the end of the slow-growth phase, cells stop dividing and enter the stationary phase, which is believed to be analogous to $\mathrm{G}_{0}$ in higher multicellular eukaryotes (Pringle and Hartwell 1981; Iida and Yahara 1984a, b). Stationaryphase cells are viable and metabolically active for a long period of time (Iida and Yahara 1984a; Boucherie 1985) suggesting that they have evolved a well-controlled mechanism to keep this activity at the lowest possible level. By using a conditional mutant, it has been demonstrated that the yeast stationary phase is a distinct "off-cell-cycle" state in the following way: Whereas these mutant cells can grow in the log phase even at the restrictive temperature and can therefore progress through all cell cycle stages normally, upon their entry 
into the stationary phase they lose their ability to resume growth while shifted to fresh medium at the nonpermissive temperature. This observation demonstrates that the mutation is not at a step that is part of the mitotic cell cycle (Drebot et al. 1987). Thus far in the literature, biochemical characterization of the stationary phase is based mainly on parameters of the postdiauxic shift phase, described above. In addition to these parameters, it also has been reported that synthesis of $95 \%$ of the proteins, detected in the log phase, is arrested in the stationary phase (Boucherie 1985). The percentage of budded cells in stationary phase is even lower than their percentage in the slow-growth phase $(>5 \%)$ (Boucherie 1985; Drebot et al. 1987). Stationary-phase cells also have been shown to be thermotolerant (Plesset et al. 1987). The stationary-phase level of few individual genes have been reported thus far; among them are $A C T 1$ (Praekelt and Meacock 1990), SSA1, SSA2, SSB1 and SSB2 (Werner et al. 1989), histone genes (Drebot et al. 1990), RAS1 (Breviario et al. 1988), UBI1 and UBI2 (Finley et al. 1987), and UBR4 (Seufert and Jentsch 1990). The mRNA levels of these genes are reduced in the stationary phase. In contrast, the mRNA levels of a few stress-induced genes have been reported to increase in the stationary phase, such as SSA3 (mentioned above), HSP26 (Petko and Lindquist 1986; Praekelt and Meacock 1990), UBI4 (Finley et al. 1989), HSP12 (Praekelt and Meacock 1990), and UBR5 (Seufert and Jentsch 1990). Interestingly, $C D C 2$ and $C D C 10$ of Schizosaccharomyces pombe, which are involved in commitment to the cell cycle, exhibit comparable levels of mRNA in all growth phases, including the stationary phase (Aves et al. 1985; Durkacz et al. 1986). The appropriate response of yeast cells to nutritional conditions depends, in part, on the cAMP-dependent protein kinase (CAPK) affector pathway. A reduced level of cAMP activity is believed to signal the diauxic shift. In mutant cells, in which cAPK activity is constitutive, the diauxic shift is not observed and cells do not exhibit the physiological changes characteristic of aerobic metabolism (Matsumoto et al. 1983; Toda et al. 1985, 1987; Cannon and Tatchell 1987). These mutants are unable to utilize a nonfermentable carbon source and are also defective in the appropriate response to the limitation of the nutrients by normal arrest in the stationary phase. When the fermentable carbohydrate is exhausted, therefore, these cells stop growing in multibudded state and lose viability upon cessation of growth (Matsumoto et al. 1983; Toda et al. 1985). Conversely, mutants defective in cAMP synthesis require exogenous cAMP for growth and become arrested in the stationary phase when cAMP is removed, regardless of the nutrient conditions (Matsumoto et al. 1982).

$S$. cerevisiae has three known DNA topoisomerases: topoisomerase I, topoisomerase II, and topoisomerase III, encoded by TOP1 (Goto and Wang 1985; Thrash et al. 1985), TOP2 (Goto and Wang 1984), and TOP3 (Wallis et al. 1989|, respectively. The function of TOP3 is still unknown. TOP2 is an essential gene whose product is required for the separation of intertwined chromosomal DNA in mitosis and for the resolution of recombined chromosomes in meiosis I (Holm et al. 1985; Rose et al. 1990). TOP1 is a nonessential gene (Goto and Wang 1985; Thrash et al. 1985/ carrying the major activity that relaxes DNA supercoils in vivo (for review, see Wang 1991). Several reports have demonstrated the involvement of topoisomerases in transcriptional regulation in vitro. Nevertheless, efforts to demonstrate involvement of topoisomerases in transcriptional regulation in vivo by inactivating both topoisomerase I and II have yielded satisfactory results only for RNA polymerase I but not for RNA polymerase II (Brill et al. 1987; Brill and Sternglanz 1988). These experiments have been carried out with cells in log phase.

Here I show that topoisomerase I has a regulatory role in the transcription of most of the genes following the diauxic shift and in the stationary phase of the yeast life cycle. In these phases, most of the genes are repressed in a temporally orchestrated manner. Efficient gene repression depends on a functional topoisomerase $I$; upon its inactivation, the repression occurs at a much slower rate. Among the repressed genes are also $S S A 3$ and HSP26, which are induced during entry into the stationary phase (as has been observed previously; see above); but upon prolonged incubation in this phase their mRNA levels decrease, by a TOP1-dependent mechanism, to the uninduced levels. In contrast to its function in transcription during the stationary phase and consistent with published data (Brill et al. 1987; Brill and Sternglanz 1988), topoisomerase I does not seem to play a major role in transcription of most genes during the log phase. Finally, it is shown that the mRNA levels of a small subset of genes remain constant in all growth phases, including the stationary phase, regardless of topoisomerase I activity.

\section{Results}

$m R N A$ levels are reduced when cells enter the stationary phase in a TOP1-dependent mechanism

A growth curve of an isogenic pair of strains, a wild-type $\mathrm{TOP}^{+}{ }^{+}$strain (SD118) and a mutant carrying a defective top1 allele (SD116), and the percentage of their budded cells along the growth is depicted in Figure 1A. These strains show a characteristic biphasic growth: a logarithmic ( $\log )$ phase in which growth is rapid, and a slower growth phase followed by a stationary phase in which the $\mathrm{OD}_{600}$ is increased at an extremely slow rate, but there is no further increase in the number of cells (results not shown; see also Werner et al. 1989). During log phase, the generation time of both strains is similar 13.6 hr for SD1 18 and $4 \mathrm{hr}$ for SD116), whereas following the diauxic shift at $\mathrm{OD}_{600}=5$ and $O \mathrm{OD}_{600}=8$ in SD118 and SD116, respectively) and during the slow growth phase, strains differ in their growth rates. The mutant exhibits a higher rate $(12 \mathrm{hr}$ vs. to $26 \mathrm{hr}$ for the wild type) and reaches a higher $\mathrm{OD}_{600}$ in the stationary phase /as well as higher cell number; results not shown). The difference in cell density in the stationary phase is observed in this 


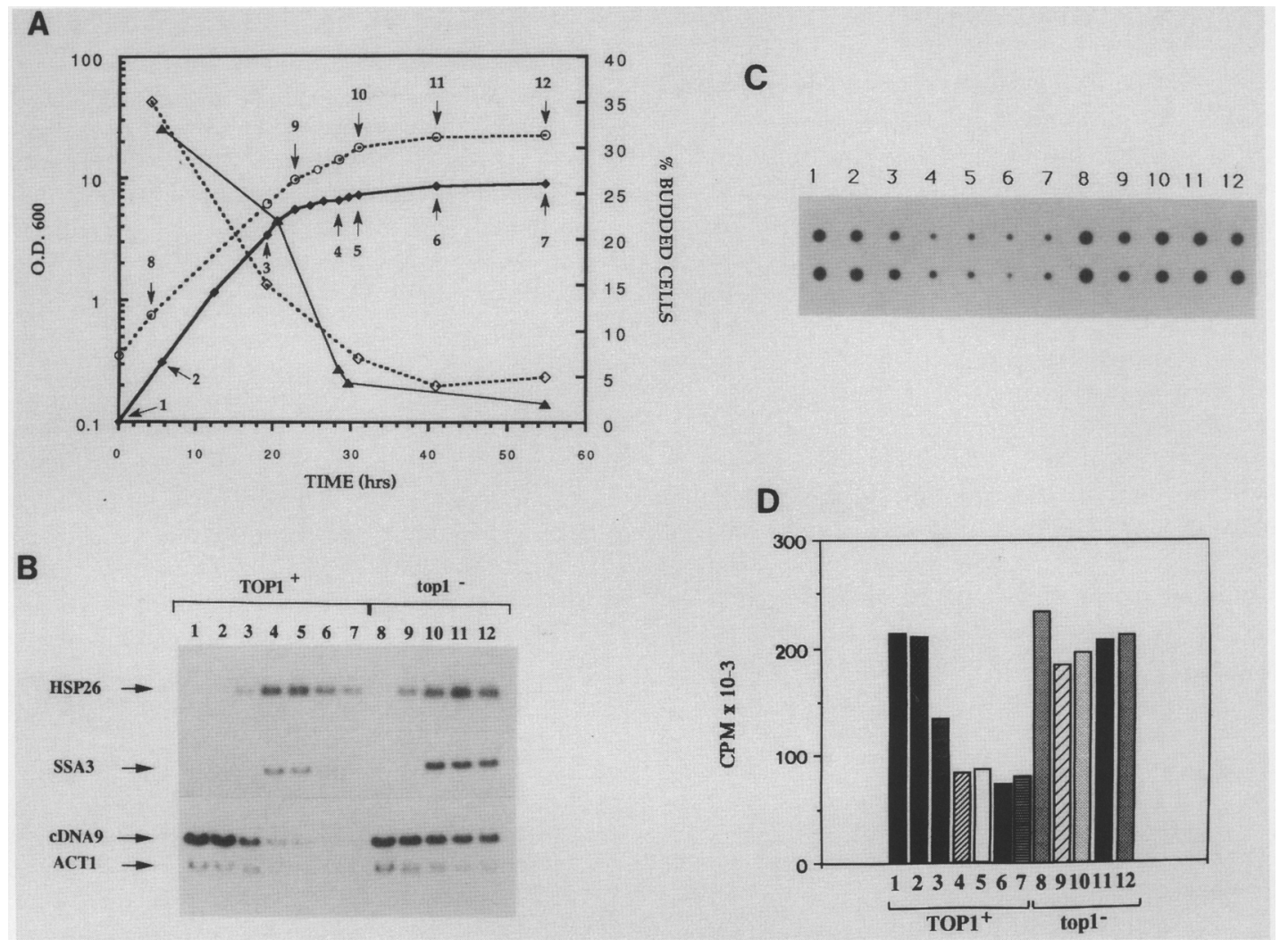

Figure 1. mRNA levels in TOP1 ${ }^{+}(\mathrm{SD} 118)$ and top1- $\left.1^{-} \mathrm{SD1} 16\right)$ as a function of growth to the stationary phase. $(A)$ Growth curve and percentage of budded cells. Cells were inoculated from culture in log phase at an initial $\mathrm{OD}_{600}$ of $0.005 .(1) \mathrm{OD}_{600}, \mathrm{SD}_{118 ;}(\mathrm{O}) \mathrm{OD}_{600}$ SD116; $(\mathbf{\Delta})$ percent of budded SD1 18; $(\diamond)$ percent of budded SD116. (Arrows 1-12) Time points at which samples were taken for mRNA analyses in $B$ and $C .(B)$ Northern blot hybridization of individual mRNAs. At various time points indicated by the arrows in $A$, equal amounts of cells were harvested and their RNA was extracted as described in Materials and methods. Four micrograms of total RNA was loaded per lane. Application of equal amounts of total RNA was verified by ethidium bromide staining of rRNA (results not shown). Following blotting, the same filter was hybridized sequentially to the indicated probes. The locations of the different mRNAs do not reflect their relative length. (C) Total mRNA levels. One microgram of total RNA was blotted onto a nitrocellulose filter in duplicate as described in Materials and methods. Blots were hybridized with ${ }^{32} \mathrm{P}$-labeled poly[d(T)]. $(D)$ Filters with individual dot blots were cut from the filter in $C$, and radioactivity was counted. The sum of duplicates is shown. Numbers 1-12 correspond to the numbered arrows in $A$.

pair when grown in galactose medium but it is not observed when glucose is used as the main carbon source. Figure 1A also shows that following the diauxic shift, in both strains, the fraction of budded cells goes down to $5-10 \%$ and is reduced further to $<5 \%$ upon the entry of the cells into the stationary phase. The low proportion of budded cells, which is characteristic of the stationary phase (Boucherie 1985; Drebot et al. 1987), demonstrates that both strains enter the stationary phase. An independent indication for entry into stationary phase is the induction of SSA3 and HSP26 (see below).

Cellular mRNA levels were examined at various time points along the growth by two assays: (1) levels of individual mRNAs, and (2) levels of total poly $(\mathrm{A})^{+}$mRNA. The total RNA was used as the basis for normalization, because it was found that total level of RNA (mainly rRNA and tRNA) is either comparable in all growth phases (in SD strains) or slightly reduced in a TOP1independent fashion, following entry into stationary phase (in $\mathrm{CH} 325 \mathrm{p}$ and $\mathrm{MC1}$ strains; results not shown). Individual mRNA levels were determined by Northern blot hybridization. Two kinds of probes were used throughout this work: DNA sequences of known genes and cDNA sequence of unidentified genes obtained from a yeast cDNA library (see below). Figure 1B shows the levels of four different mRNAs: the levels of ACT1 mRNA and mRNA9 in the wild-type strain drop following the diauxic shift (Fig. 1B, lanes 4-7), whereas they remain either constant (mRNA9) or only slightly reduced (ACT1 mRNA) in the top1 mutant following the diauxic shift (Fig. 1B, lanes 9-12). SSA3 and HSP26 mRNA levels in both strains are very low in log phase and increase following diauxic shift. Their induction has been shown previously to be a characteristic of the postdiauxic shift phase, as described above. When the wildtype strain stays in the stationary phase for a longer period of time, SSA3 and HSP26 mRNAs levels gradually decrease (Fig. 1B, lanes 6,7). This decrease is also depen- 
dent on TOP1 as it is not observed in the mutant (Fig. 1B, lanes 11,12). Furthermore, SSA3 mRNA induction is slightly lower in the $T O P 1^{+}$strain as compared with the top1- strain (Fig. 1B, cf. lanes 4, 5, and 10). This difference may reflect the fact that in the wild type, induction and repression of SSA3 occur simultaneously following diauxic shift. In the mutant, on the other hand, the SSA3 mRNA level reflects the net level of induction when repression does not occur. Figure 1, C and D, shows the results of total mRNA levels at various growth stages. Similar to ACT1 mRNA and mRNA9, shown in Figure $1 B$, the total mRNA level of the wild type decreases when cells progress to stationary phase. In the mutant, no significant reduction in the total mRNA level is observed. When the levels of several individual mRNAs were examined, very few mRNA species showed reduction in stationary phase in the mutant as well; those that did were reduced at lower rates than in wild type (e.g., ACT1 mRNA as opposed to mRNA9 in Fig. 1B). That the total mRNA level in the mutant was comparable in all phases suggests one of two possibilities or a combination of both: (1) The population of genes with mRNA levels slightly decreased in stationary phase produce a minor fraction of the total mRNAs, and (2) the induction of some genes occurring at late stages of growth balances the reduction of others.

Results in Figure 1 demonstrate a topoisomerase I-dependent reduction in the total mRNA level as well as in the individual gene transcripts in the SD118 strain. A topoisomerase I-dependent reduction of individual mRNA levels is also observed in four other TOP $1^{+}$ strains. Three, shown in Figure 2, are JCW5 and JCW6, which have a similar genetic background, and SD117, which is similar to SD118. The fourth strain, CH325p, is shown in Figures 3 and 4, below. Figure 2 shows that during the stationary phase in each of these strains, the mRNA9 or ACT1 mRNA levels are lower than levels in the corresponding top1 isogenic mutant. The mRNA lev- els of SSA3 and HSP26, which are not detectable in the log phase, are increased in the stationary phase, demonstrating that cells were in the postdiauxic shift. Results in Figure 2 also suggest that the mRNA levels are not affected by a perturbation of topoisomerase II activity encoded by the temperature-sensitive top 2.4 allele, when cells are grown at $25^{\circ} \mathrm{C}$. The top $2-4$ product has a significantly reduced activity even at $25^{\circ} \mathrm{C}$, the permissive temperature. This argument is based on previous results showing that when both TOP1 and TOP2 are inactivated, rDNA sequences are excised from the chromosome and found as extrachromosomal rings and that the TOP2 product can prevent rDNA excision while the top2-4 product is incapable of preventing the excision at $25^{\circ} \mathrm{C}$ (Kim and Wang 1989). This loss of function demonstrates that the top $2-4$ product has a significantly reduced activity even at $25^{\circ} \mathrm{C}$. Here, it is shown that in the stationary-phase ACT1 mRNA and mRNA9 in both TOP $1^{+}$and top $1^{-}$strains are not affected by the TOP2 allele, whether it is wild type (Fig. 2, lanes TOP2+) or top2-4 (Fig. 2, lanes top2-4). This suggests that the TOP1 product is the major topoisomerase involved in the regulation of mRNA levels following the diauxic shift and in the stationary phase. The results do not rule out the possibility that topoisomerase II fails to substitute topoisomerase I only as a result of down-regulation, of topoisomerase II following the diauxic shift.

mRNA levels in petite strains are dramatically reduced in the stationary phase in a TOPl-dependent mechanism

Strains defective in the respiratory pathway (petite) can grow as long as a fermentable carbon source in the medium is at a level high enough to support fermentation. At the end of log phase, when this carbon source is depleted, petite strains must enter stationary phase rapidly
Figure 2. Reduced level of mRNA in the stationary phase is dependent on a functional topoisomerase I, irrespective of the genetic background. (Left) JCW5 (TOP1 ${ }^{+}$, TOP2 $\left.{ }^{+}\right)$, JCW7 (top ${ }^{-}$, TOP2 $\left.{ }^{+}\right)$, JCW6 (TOP1 ${ }^{+}$, top2-4), and JCW8 (top1 ${ }^{-}$, top24) were grown in YPDA medium to the stationary phase. Cells were harvested either at $\log$ phase at $\mathrm{OD}_{600}=1(\log )$, or upon entry into stationary phase at $\mathrm{OD}_{600}=27 \quad$ (S.P.), and RNA was extracted. Ten micrograms of total RNA was analyzed by Northern blot hybridization with the indicated DNA as probes. (Right) SD118 (TOP1 ${ }^{+}$, TOP2 $^{+}$), SD116 (top ${ }^{-}$, $\mathrm{TOP2}^{+}$), SD117 (TOP1 ${ }^{+}$, top2-1), and SD119 (top ${ }^{-}$, top2-1) were grown to the stationary phase. Three hours before the diauxic shift (late $\log$ ) or a few hours after entering the stationary phase (S.P.), cells were harvested and RNA was extracted and analyzed as in $A$.

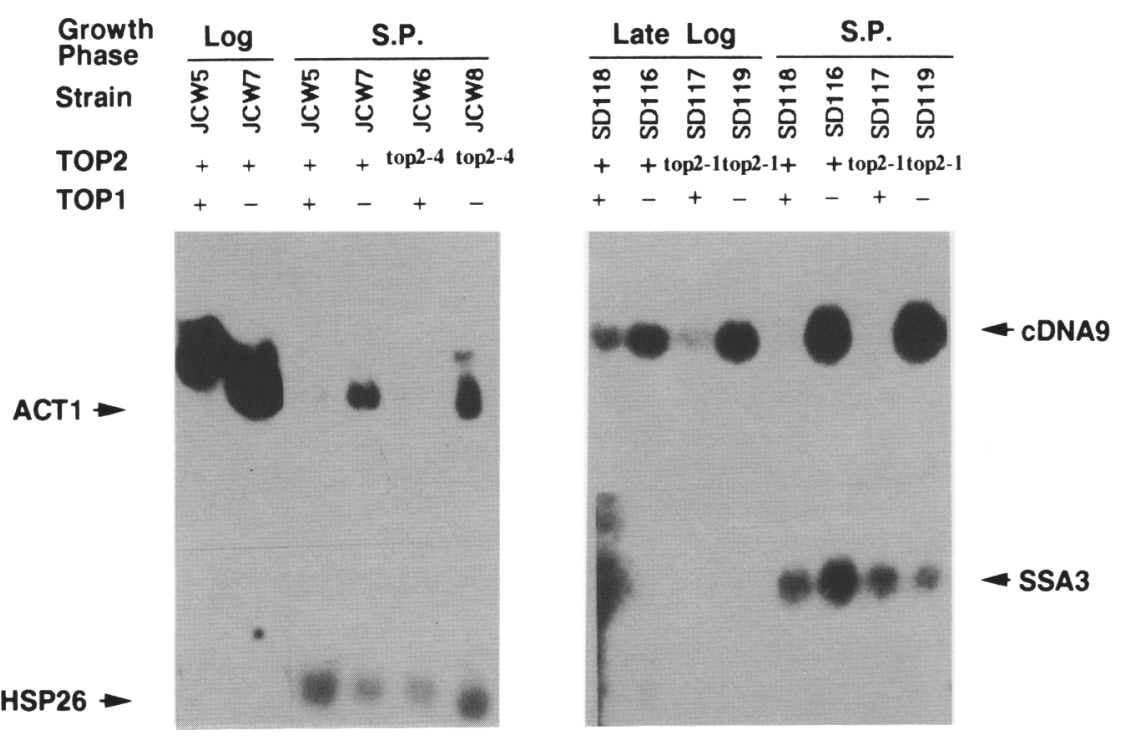


to survive (see Discussion). Petite strains may therefore serve as a convenient model system to study the rapid entry of a cell into the stationary phase. Figures 3,4 , and 7 (below) show that mRNA levels in a petite $\left(T O P 1^{+}\right)$ strain are reduced dramatically and rapidly at the end of the log phase of the cell and upon their entry into the stationary phase.

Figure 3A depicts a growth curve of $\mathrm{CH} 325 \mathrm{p}$, a spontaneously arising $\mathrm{Gly}^{-}$strain. Unlike respiratory-competent strains (e.g., SD118 in Fig. 1A), CH325p does not show diauxic growth but, rather, enters stationary phase immediately following the end of log phase. The percentage of budded cells of $\mathrm{CH} 325 \mathrm{p}$ in stationary phase was $6 \%$, and cells did not lose viability for at least 10 days in this phase in YPDA medium (results not shown). Figure 3, B and C, shows that the total mRNA level drops 17fold within a period of $\sim 4 \mathrm{hr}$, and 35 -fold after $\sim 40 \mathrm{hr}$ in the stationary phase.

The TOP1 gene was deleted from the $\mathrm{CH} 325 \mathrm{p}$ strain to investigate its involvement in this dramatic reduction in mRNA levels following the entry of the cell into stationary phase. To verify that the phenotype of the top1 null mutant is the result of deletion of the TOP1 gene and not of a nonspecific mutation that could arise during transformation, eight independent deletion mutants were analyzed. Deletion of the TOP1 gene was verified by Southern blot hybridization and Western analysis (not shown). In stationary-phase, the $\mathrm{OD}_{600}$ of the mutant is similar to that of the parental strain (not shown). RNA was isolated from the eight independent mutants $30 \mathrm{hr}$ after the cells entered stationary phase, and their total mRNA was compared to that of the parental strain. In all eight independent top1 $\left(\mathrm{Gly}^{-}\right)$mutants the total mRNA level is higher than in the parental strain (Fig. 4A). The total
mRNA level in another petite strain $\mathrm{CH} 325 \mathrm{p} 1$, which arose spontaneously from $\mathrm{CH} 325$ as well, is comparable to that in the parental strain (Fig. 4A). The levels of individual mRNAs in four of the top 1 mutants, $30 \mathrm{hr}$ after they entered stationary phase, were analyzed further by Northern blot hybridization, as shown in Figure 4B. The results demonstrate that stationary-phase levels of mRNA82 and HSP26 mRNA are dramatically higher in all of these mutants as compared with both TOP1 ${ }^{+}$ strains: the parental $\mathrm{CH} 325 \mathrm{p}$ and $\mathrm{CH} 325 \mathrm{pl}$. The low level of HSP26 mRNA in the TOP $1^{+}$strains (Fig. 4B) is characteristic of $\mathrm{TOP}^{+}$cells remaining longer than 1 day in the stationary phase (Fig. 4C, lanes 4-6). One of the top1 mutants was analyzed further. A comparison between the mRNA levels in this mutant and in the parental cells during various growth stages is shown in Figure 4C. It is evident that the levels of mRNA82 and mRNA9 in the parental $\mathrm{CH} 325 \mathrm{p}\left(\mathrm{TOP}{ }^{+}\right)$strain are reduced dramatically after cells enter the stationary phase (Fig. 4C, lanes 4-6). The levels of these mRNAs decline with different kinetics. While the mRNA9 level decreases dramatically when cells just enter stationary phase, a reduction in the mRNA82 level is gradual as cells progress to stationary phase. Although the relative levels of mRNA9 and mRNA82 seem to be similar at early log phase (Fig. 4C, lane 1), they are different at 3.5 $\mathrm{hr}$ after entry into stationary phase (Fig, 4C, lane 4). This difference suggests that the mechanism that reduces mRNA levels is specific and well controlled (see also Fig. 6 , below). In the top1 mutant, the mRNA levels do decrease, but at a much slower rate than in the TOP ${ }^{+}$ isogenic strain. Decrease in the mRNA82 level can be observed only after the mutant cells stay in stationary phase longer than $24 \mathrm{hr}$, whereas in the parental strain,
A

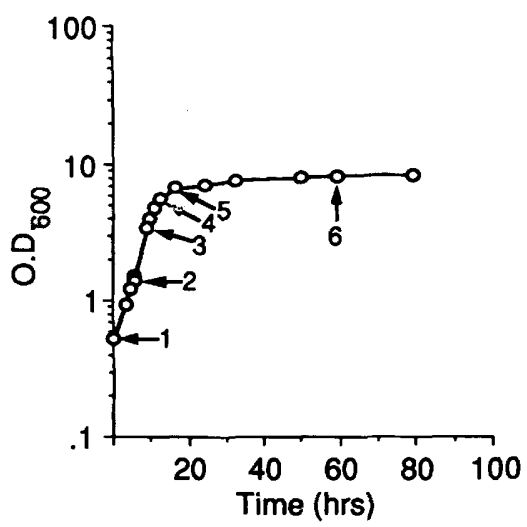

C

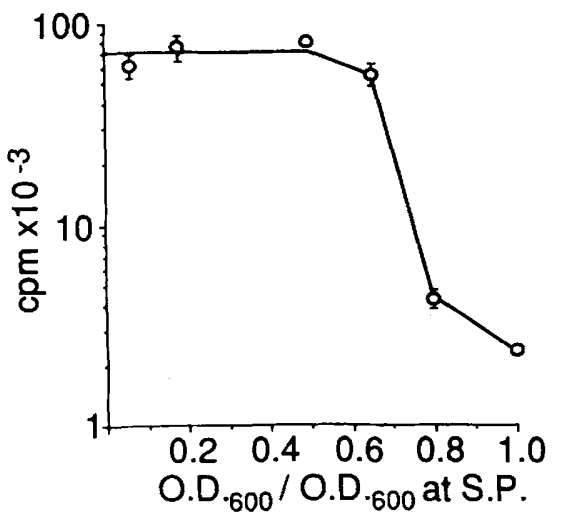

Figure 3. mRNA levels in a petite $T O P 1^{+}$strain as a function of growth to the stationary phase. $(A)$ Growth curve of $\mathrm{CH} 325 \mathrm{p}$ in YPDA medium. (Arrows 1-6) Time points at which samples were taken for the mRNA analyses in $B$. (B) Total mRNA levels at various growth stages of $\mathrm{CH} 325$ p determined by dot blots in duplicates, as in Fig. 1C. Numbers correspond to arrows in $A$. $(C)$ Quantitative representation of the results in $B$. Filters with individual dot blots were cut from the filter in $B$ and radioactivity was counted. Radioactivity of an average of duplicates was plotted as a function of the growth stage, which is expressed as the ratio between $\mathrm{OD}_{600}$ at harvest and $\mathrm{OD}_{600}$ at the stationary phase (S.P.). The stationary phase sample (expressed as 1 in the graph) was taken 2 days after the cells entered this phase. Note the logarithmic scale. 
Figure 4. mRNA levels in $\mathrm{MCl}\left(\right.$ top $\left.1^{-}\right)$ mutants as compared with their parental isogenic strain $\mathrm{CH} 325 \mathrm{p}\left(\mathrm{TOP}^{+}{ }^{+}\right)$. (A) Total mRNA levels in the stationary phase in $\mathrm{CH} 325 \mathrm{p}$ and $\mathrm{CH} 325 \mathrm{p} 1$ (an independent petite colony spontaneously aroused from $\mathrm{CH} 325$ ) as compared with eight independent isogenic top1 deletion mutants $(\mathrm{MCl}$ strains). Strains were grown in YPDA medium and harvested 1 day after cells entered the stationary phase. Total mRNA levels were assayed as in Fig. 1C. Results of triplicates are shown. $(B)$ Northern blot hybridization of RNA described and assayed in $A$ was carried out as in Fig. 1B, by using the indicated probes. $\mathrm{CH} 325 \mathrm{p}$ (lane 1); $\mathrm{CH} 325$ p (lane 2); MCl-1 (lane 3); MCl-2

$\underline{A}$

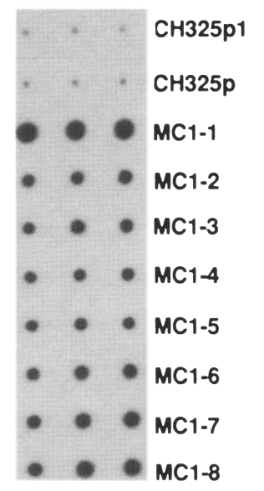

B

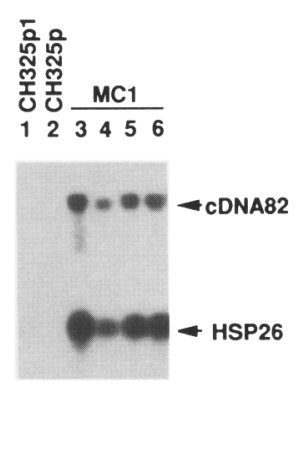

$\underline{\mathrm{C}}$

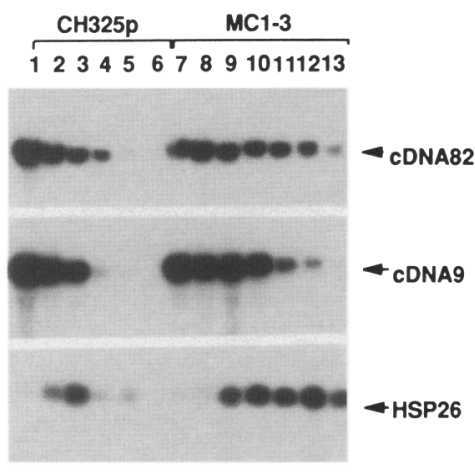
2 (lane 4); $\mathrm{MCl}-3$ (lane 5); MC1-4 (lane 6). (C) Northern blot hybridization of $\mathrm{CH} 325 \mathrm{p}$ and MC1-3 individual mRNAs. At various stages of growth and during various times in the stationary phase, RNA was extracted and analyzed as in Fig. 1B. RNA was taken from CH325p cells (lanes 1-6) or from MC1-3 (lanes 7-13) at the following growth stages: lanes 1-3 at stages $0.51,0.72$, and 1, respectively (calculated as in Fig. 3C); lanes $4-6$ at $3.5 \mathrm{hr}, 24 \mathrm{hr}$, and 4 days after entry into the stationary phase, respectively; lanes $7-10$ at $0.4,0.65,0.86$, and l, respectively (calculated as in Fig. 3C); lanes 11-13 at $2.5 \mathrm{hr}, 24 \mathrm{hr}$, and 4 days after entry the stationary phase, respectively. The locations of the different mRNAs do not reflect their relative length.

the beginning of the reduction in mRNA levels can be observed even before cells reach stationary phase. Likewise, $24 \mathrm{hr}$ after mutant cells enter the stationary phase, the level of mRNA9 is higher than its level in the $T O P 1^{+}$strain after $3.5 \mathrm{hr}$ in stationary phase (cf. Fig. $4 \mathrm{C}$, lanes 12 and 4). HSP26 is induced in both TOP1 ${ }^{+}$and top $1^{-}$strains when cells progress to the stationary phase and reaches its highest level when they enter the stationary phase. However, the HSP26 mRNA level does decrease after cells remain in the stationary phase for a longer period of time. As quickly as $3.5 \mathrm{hr}$ after $\mathrm{CH} 325 \mathrm{p}$ enters stationary phase, the HSP26 mRNA level drops and is only slightly higher than its level at the uninduced state (Fig. 4C, cf. lanes 4 and 1). It remains at this semiinduced state for at least one more day but by the end of 4 days its level is comparable to the uninduced state. In contrast to the parental $\mathrm{TOP}^{+}$strain, in the top $1^{-} \mathrm{mu}$ tant, no reduction in HSP26 mRNA is observed within 4 days in the stationary phase.

These results demonstrate that although more aggressive than in respiratory-competent strains (cf., e.g., Fig. 1 C and D, with Fig. 3, B and Cl, the mechanism to reduce mRNA levels in the petite strain is, as in respiratorycompetent cells, also dependent on a functionally active topoisomerase I.

\section{TOP1-dependent transcriptional repression in the stationary phase}

The result that the reduction of mRNA levels in stationary phase is dependent on topoisomerase I, an enzyme that uses DNA as a substrate, suggests that this reduction is due to transcriptional repression. To assay the transcription rate, cells were pulse labeled with radioactive orthophosphate $\langle\mathrm{Pi}\rangle$, and the extent of ${ }^{32} \mathrm{P}$ incorporation into total mRNA was monitored as described in Materials and methods and in Figure 5.
Figure 5 shows that the incorporation rate of $\mathrm{Pi}$ into poly $(A)^{+}$mRNA is 3.7-fold higher in SD1 $16\left(\right.$ top $\left.1^{-}\right)$than in SD118 $\left(\mathrm{TOP}^{+}{ }^{+}\right)$. This difference is similar to the difference in the total mRNA levels in stationary phase in these strains (see Fig. 1D).

Earlier experiments demonstrated that petite strains differ from respiratory-competent strains in their ability to take orthophosphate while cells are in the stationary phase. Although the uptake of $\mathrm{Pi}$ is still efficient $24 \mathrm{hr}$ after entry of respiratory-competent cells into stationary phase, Pi uptake by the petite strain is reduced 20 -fold at $3.5 \mathrm{hr}$ after entry into stationary phase as compared with the uptake in log phase and early stationary phase. Labeling of the petite pair was therefore carried out either at the late stages of log phase or just when cells entered stationary phase. CH325p $\left(\mathrm{TOP}^{+}{ }^{+}\right)$and $\mathrm{MCl}-3$ (top $1^{-}$) cells were treated at various late stages of growth as follows: Each sample was divided into two aliquots: one aliquot was labeled for $10 \mathrm{~min}$ and treated as described above; RNA of the other aliquot was extracted and analyzed by Northern blot hybridization (Fig. 4C, lanes 1-3 and 7-10). The pulse-labeling results, shown in Figure 5, demonstrate that in the $\mathrm{TOP}^{+}$petite strain there is a significant decrease in the incorporation rate into total mRNA before cells enter stationary phase. In contrast, the polymerase II transcriptional rate in the top $1^{-}$petite strain was comparable at all times throughout log phase. Only upon entry into stationary phase is there some reduction in transcriptional rate, which is still higher than its rate in the $T O P 1^{+}$at this growth stage. Comparing the results in Figures $4 \mathrm{C}$ and 5 indicates that in the $\mathrm{TOP}^{+}$strain, but not in the mutant, both the mRNA82 and mRNA9 levels and the general transcriptional rate are decreased before entry into the stationary phase $\mathrm{cf}$. lanes $1-3$ and $7-10$ in Fig. 4C with the corresponding samples in Fig. 5).

Taken together, the results obtained with the two dif- 
ferent pairs indicate that RNA polymerase II transcription is repressed in the late log and the stationary phases by a topoisomerase I-dependent mechanism.

Expression of most genes present in the cDNA library is repressed during the stationary phase by the topoisomerase I-dependent mechanism

To evaluate the generality of the repression phenomenon, a random population of mRNA was analyzed by screening a yeast cDNA library, as schematized in Figure 6A. Specifically, an isogenic pair of strains (SD118 and SD116) were harvested at the mid-log phase and at the stationary phase, and their mRNAs were partially purified by an oligo[d(T)] column. Labeled cDNA was prepared from these mRNAs by reverse transcription, and an equal amount of radioactivity was hybridized to filters containing a yeast cDNA library in $\lambda g t 10$. Any resulting radioactive spot corresponds to one gene, and its relative intensity reflects the relative abundance of its mRNA in the cell at the time of harvest. The relative spot intensities were determined from a comparison of autoradiograms at different exposure times. Following the exposure to X-ray films, filters were stripped of the first probe and then hybridized to a second probe corresponding to labeled cDNA from the other strain. The filters were exposed to X-ray film and again stripped of the probe, and a third hybridization was done with phage $\lambda$ DNA. Hybridizations were performed in this sequence to eliminate false positives. The four filters shown in Figure 6 are designated here as $\log \mathrm{TOP}^{+}{ }^{+}$filter, $\log$ top $1^{-}$filter, stationary-phase TOP1 ${ }^{+}$filter, and stationary-phase top $1^{-}$filter.

The total amount of radioactive cDNA in each labeling reaction reflected the total amount of mRNA in the labeling reaction. Consistent with the results shown in Figures 1-4, the labeled cDNA obtained from mRNA of the $\mathrm{TOP}^{+}$strain in stationary phase was lower than that obtained in the other samples (results not shown). Thus, if equal amounts of radioactivity are hybridized, as was done in this experiment, any radioactive spot appearing in the stationary-phase $T O P 1^{+}$filter is derived from labeled cDNA from more cells than the same spot is in the other filters. Following the same logic, any spot whose intensity in the stationary-phase $T O P 1^{+}$filter is comparable (or lower) to its intensity in the $\log T O P 1^{+}$ filter indicates that the corresponding mRNA level is lower in the stationary phase than in the log phase (evidence supporting this logic is provided by results shown in Figure 7, in which mRNA levels were directly examined; see below).

Figure 6B provides an example of $\sim 50$ spots of $\sim 400$ spots scored. The results, based on comparison of the spot intensities in the four filters, are discussed in the following order: (1) comparison of spot intensities in the two $\log$ filters, (2) comparison of the log top $1^{-}$filter with the stationary-phase top $1^{-}$filter, and (3) comparison of the stationary-phase TOP $1^{+}$filter with the other three filters.
1. Comparison of spot intensities in the two log filters showed no differences that were significant $(>3 \times)$ and consistent in all the sequential hybridizations described before. These results suggest that when cells are in their log growth phase, topoisomerase I is not essential for normal expression of at least most genes. This result is also consistent with published observations (Brill et al. 1987; Brill and Sternglanz 1988).

2. Comparison of spot intensities in the log top $1^{-}$filter with the stationary-phase top $1^{-}$filter showed similar intensities of most of the spots. This result is consistent with the observation that in the top1 mutant the total mRNA level, as well as mRNA levels of individual genes, is comparable in all growth phases including the stationary phase (Fig. 1).

3. The stationary-phase TOP1+ filter reveals two groups of spots: Most $(\sim 95)$ can be categorized as having either equal or lower intensities compared with their intensities in the other filters. These spots may represent a class of genes that exhibit reduced mRNA levels in the stationary phase. A representative of this group is spot 82, marked by an arrow in Figure 6B. It is important to note that all genes exhibiting reduc-

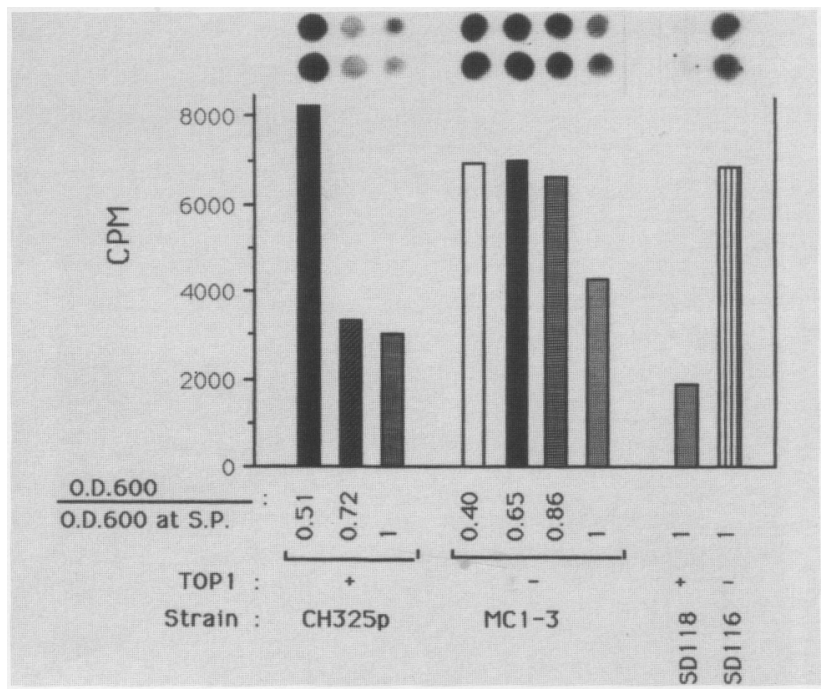

Figure 5. Transcriptional rate of RNA polymerase II-transcribed genes in TOP $1^{+}$and top $1^{-}$strains. Cells were grown in YPD-Pi medium and labeled at either $24 \mathrm{hr}$ after entry into the stationary phase (SDI 18 and SD116) or at the indicated growth phases $(\mathrm{CH} 325 \mathrm{p}$ and $\mathrm{MC} 1-3)$. Equal amounts of cells $\left(8 \times 10^{7}\right)$ were labeled for either $6 \mathrm{~min}$ (SD118 and SD116) or $10 \mathrm{~min}$ $(\mathrm{CH} 325 \mathrm{p}$ and $\mathrm{MCl}-3)$ at $25^{\circ} \mathrm{C}$, as described in Materials and methods. RNA samples were extracted, and their concentrations were measured by $\mathrm{OD}_{260}$. Radioactivity in total mRNA was determined by spotting duplicates of $1.25 \mu \mathrm{g}$ of total RNA (derived from comparable amount of cells) onto Hybond mAP filter (Amersham), followed by washing twice for $10 \mathrm{~min}$ and once for $30 \mathrm{~min}$ with $0.5 \mathrm{M} \mathrm{NaCl}$ to remove poly(A) ${ }^{-}$RNA and DNA. Following exposure of the filter to $\mathrm{X}$-ray film, mRNA was eluted by water at $65^{\circ} \mathrm{C}$ and counted. The eluted RNA did not contain DNase I-digestible counts (not shown). An autoradiogram is shown at the top. Growth stages are expressed as in Fig. 3C. 
tion in mRNA levels in stationary phase are repressed by a TOP1-dependent mechanism. This is because genes in the wild-type cells that are repressed in the stationary phase have comparable or higher intensity in the stationary-phase top $1^{-}$filter (i.e., they are less repressed or not repressed at all in the top $1^{-}$mutant). Comparison of spot intensities of individual genes in the $\log \mathrm{TOP}^{+}$filter and in the stationary-phase $\mathrm{TOP}^{+}{ }^{+}$filter reveals that different genes are repressed to different extents. This observation is in accord with results shown in Figure 4C, demonstrating that repression is temporally orchestrated and therefore probably well-controlled.

A minor population of spots shown in the stationaryphase $T O P 1^{+}$filter $(\sim 5 \%$ of the spots) have much higher intensities in this filter than in the other filters. Representatives of this group are spots 74 and 75 (Fig. 6B).

To examine the mRNA levels from representatives of each class of genes, the following experiment was performed. The yeast DNA sequence of the representative plaque DNAs were amplified by PCR, labeled, and used as probes to check the level of their mRNAs at various growth stages (see Materials and methods). The results, shown in Figure 7, clearly show that mRNA82 level drops to an undetectable level when the TOP1 ${ }^{+}$strain enters stationary phase. In contrast, mRNA74 levels /and also mRNA75; results not shown) were comparable during all growth phases including the stationary phase.
Taken together, the results in Figures 6 and 7 demonstrate that the mRNA levels of most genes present in the cDNA library are reduced in stationary phase by a TOP1dependent mechanism. The mRNA levels of a minor population of genes do not change when cells enter the stationary phase both in $T O P 1^{+}$and in top $1^{-}$strains. RPB4 (encodes a subunit of RNA polymerase II) and YAKl (encodes a protein kinase) were found to be members of the latter minor population (results not shown). This analysis failed to detect a third population of genes in which the mRNA levels are induced in the stationary phase. This is most likely the result of the low abundance of this class in the library examined, as the library was made from log-phase cells. Known examples of genes of this group are HSP26 and SSA3, which were analyzed individually and shown in Figures 1, 2, and 4.

\section{Discussion}

The main conclusion of the data presented here is that a general topoisomerase I-dependent repression mechanism operates in batch cultures of $S$. cerevisiae following the diauxic shift and in the stationary phase. The TOP1dependent repression is not strain specific, as was observed in several different strains (SD118, SD117, JCW5, JCW6, CH325p). It was observed in respiratory-competent cells grown on either dextrose or galactose as the main carbon source and in respiratory-defective cells grown on dextrose. This repression mechanism probably

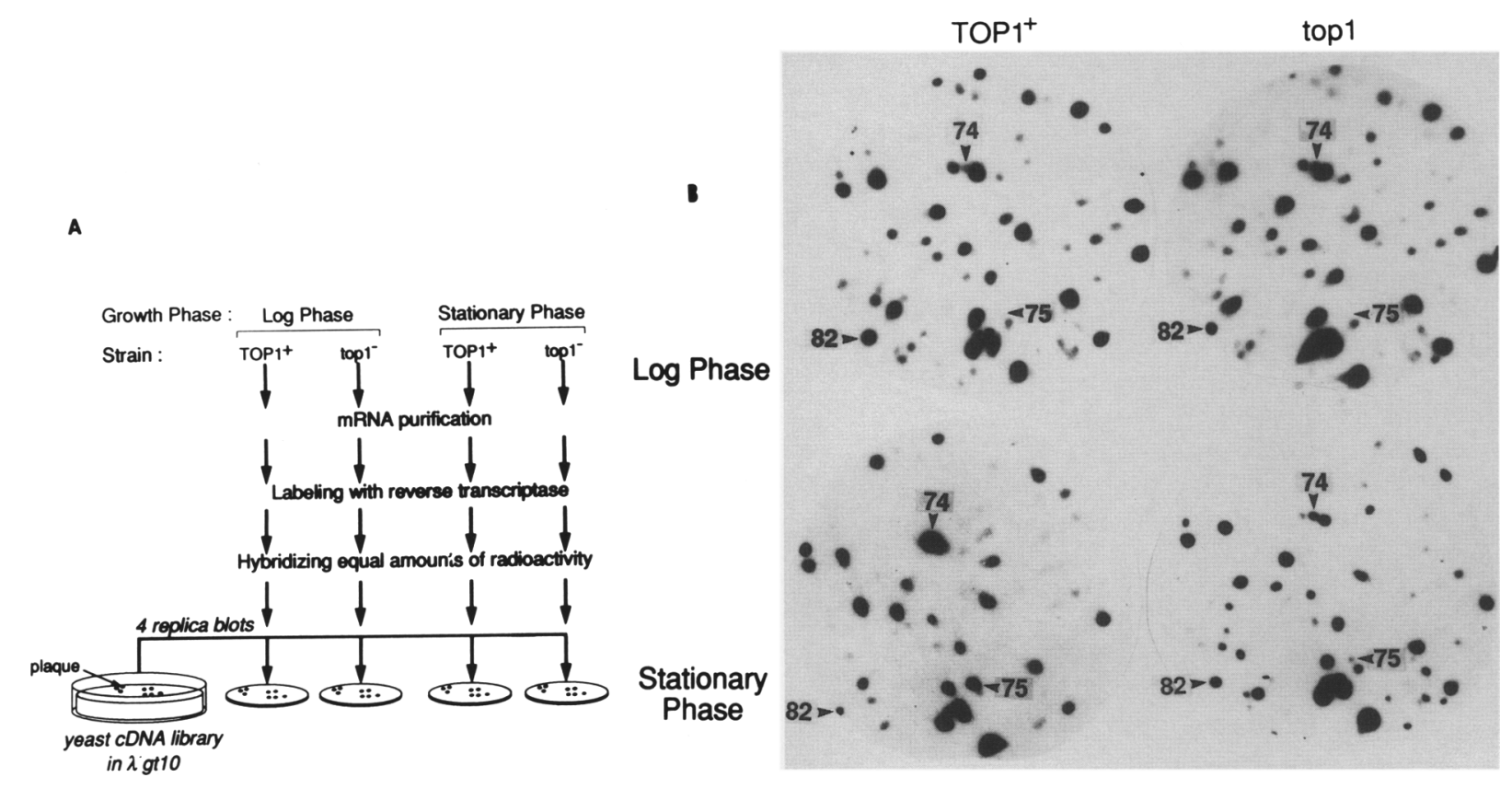

Figure 6. Hybridization of labeled cDNA from $T O P 1^{+}$and top $1^{-}$cells in either log or stationary phase to four plaque filter replicas. (A) Experimental design. Four filter replicas were made by blotting a single plate having plaques of hybrid $\lambda \mathrm{gt} 10$ containing the yeast cDNA library. To prepare the probes, SD118 $\left(\mathrm{TOP}^{+}\right)$and SD116 (top $\left.1^{-}\right)$cells were harvested in either log or stationary phase. RNAs were extracted, and mRNAs were fractionated by oligo[d(T)] column and labeled by reverse transcription with oligo[d( $\left.\left.\mathrm{T}_{12-18}\right)\right]$ as primer and radiolabeled precursor. The same amount of ${ }^{32} \mathrm{P}$-labeled cDNA was hybridized to each filter. Numbered arrows indicate plaque DNAs that were used further as probes for Northern blot hybridization (see Fig. 7). Note that in TOP1 ${ }^{+}$cells in the stationary phase, there is less total mRNA, which is reflected in the extent of labeling (not shown; see text). (B) Autoradiograms of four filter replicas prepared and probed as described in $A$. 


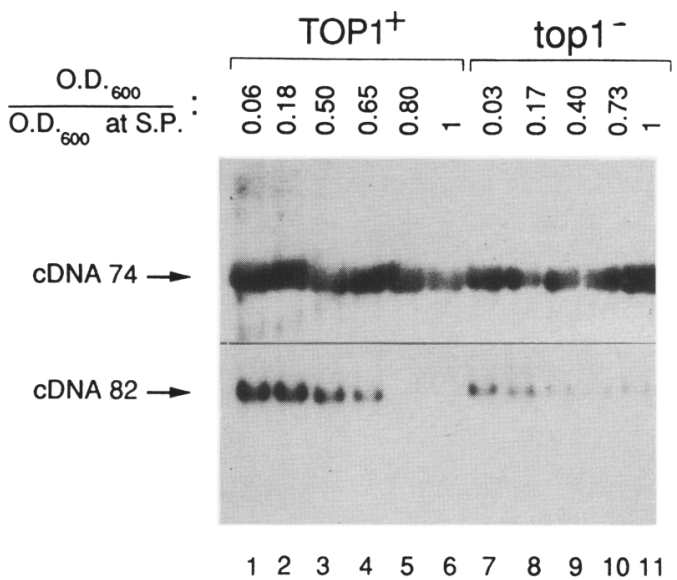

Figure 7. Levels of mRNA 74 and mRNA82 in a TOP1 ${ }^{+} /$top $1^{-}$ isogenic pair grown to the stationary phase. TOP $1^{+}(\mathrm{CH} 325 \mathrm{p})$ and top $1^{-}(\mathrm{MC} 1-3)$ were grown in YPDA to the stationary phase. At various growth stages, RNA was extracted and analyzed as in Fig. 1B. Probes were prepared as follows: Yeast DNA inserts present in the hybrid phages, 74 and 82 in Fig. 6B, were amplified by PCR with oligonucleotide of the vector sequence near the insert/vector junction. The amplified insert was gel purified and labeled as in Materials and methods. Growth stages are expressed as in Fig. 3C. The stationary-phase sample was from cells at 2 days after entry into the stationary phase.

operates on most of the genes, as analysis of a random population of cDNAs demonstrated that the mRNA levels from $\sim 95 \%$ of the genes examined was reduced in a TOP1-dependent mechanism. In addition, total mRNA level in the petite strain is 35 -fold lower in the stationary phase than it is in the log phase. This observation is in accord with the result that synthesis of $95 \%$ of the proteins, detected in log phase, is arrested when cells enter stationary phase (Boucherie 1985), indicating that the translational arrest is due, in part, to a low level of mRNA. Analyses of few individual genes (Fig. 4C) and screening random population of cDNAs (Fig. 6B) show that this repression mechanism is orchestrated in a specific temporal way. Thus, different genes are repressed at different time frames during the growth to stationary phase. Furthermore, not all genes are repressed. A small fraction of genes $(-5 \%$ of the genes in the population studied) maintain a comparable mRNA level at all growth phases. Strikingly, the levels of these mRNAs are not changed even in the petite strain cells, in late stationary phase when the total mRNA level is 35 -fold lower than that in log phase, and when even SSA3 and HSP26 mRNA levels are already reduced to their uninduced level. These genes are not stationary phase specific because they are transcriptionally active in the log phase as well. The stationary phase-specific genes could not be detected by screening the particular cDNA library used in this study, probably because the library was made from cells growing in the log phase. Nevertheless, it is likely that the functions of at least some of the genes that have comparable mRNA levels in all growth phases have relevance in maintaining cell viability in the stationary phase.
While the mRNA levels of most genes are gradually reduced following the diauxic shift and some of them are maintained at a comparable level in all growth phases, the stress genes SSA3 and HSP26 display distinct pattern of expression. Their mRNA levels are very low in log phase and are induced following the diauxic shift and upon entry into stationary phase (Petko and Lindquist 1986; Boorstein and Craig 1990a; Figs. 1B and 4C), but they are gradually reduced again to their levels in log phase after prolonged incubation in the stationary phase. This behavior suggests that those genes do not escape the general repression imposed on most of the genes. In fact, it is likely that their repression is initiated simultaneously with their induction, that is, immediately following diauxic shift. Indeed, in SD116, a top $1^{-}$strain in which repression is very inefficient, the SSA3 mRNA level immediately following diauxic shift is higher than its level in the wild type (SD118) at the same growth stage (Fig. 1B).

The general repression of most genes is a well-controlled process. This conclusion is based on a combination of the following observations: (1) the temporal repression of individual genes; (2) the induction of SSA3 and HSP26 following the diauxic shift, when most genes are repressed, and their gradual repression in late stationary phase; (3) the unchanged mRNA levels of a small subset of genes in all growth phases; and (4) the involvement of topoisomerase I in the repression.

Mutant cells defective in topoisomerase I do not lose viability in rich medium within a period of at least 32 days (results not shown), suggesting that the transcriptional repression is not the only mechanism involved in arresting growth to prevent cell death. The cellular response to the slower repression kinetics in top $1^{-}$strains is dependent on the genetic background and on the growth conditions. Thus, in media containing galactose, but not dextrose, SD116 (top $1^{-}$) reaches higher cell density in the stationary phase than SD118 $\left(T O P 1^{+}\right)$. Similar difference in cell density was observed in the SD117 (TOP1 ${ }^{+}$)/SD119 (top1-) pair (not shown here). In contrast to SD116 (top1 ${ }^{-}$) and SD119 (top1- , top2 ts), the density of the cells JCW7 (top $1^{-}$) and JCW8 (top $1^{-}$, top2 $t s$ ) in stationary phase is comparable to their isogenic $\mathrm{TOP}^{+}$strains in both galactose medium and dextrose medium (but they show a TOP1-dependent repression in this phase; see, e.g., Fig. 2). The higher cell density of the SD top $1^{-}$strains, as compared with their isogenic $\mathrm{TOP}_{1}{ }^{+}$strains, suggests that in these strains the transcriptional repression is the rate-limiting mechanism in arresting cell growth, at least in the slow-growth phase. In contrast to $S D$ strains, the rate-limiting mechanism to arrest growth in JCW strains is a transcriptional and TOP1-independent process (translational arrest?). Cells of both genetic backgrounds enter the stationary phase at either earlier stages (as a result of a possible strong transcriptional independent process) or later (the result of a very slow but detectable TOP1-independent transcriptional repression) and cells remain viable.

In this study a new model system has been introduced for studying the stationary phase-the respiratory-defec- 
tive (petite) strains. As long as a fermentable carbohydrate is not limited, petite strains grow at a slightly slower rate than the growth rate of their parental respiratory-competent cells. At the end of log phase when fermentable carbohydrate is depleted, the petite strains rapidly enter stationary phase. This is to be expected when the fermentable carbon source reaches a critically low level. Normally, this would signal fermentation repression and induction of aerobic metabolisms, all of which occur during the diauxic shift, (see introductory section). Spontaneous petite mutations arise frequently $(\sim 1 \%$ in many laboratory strains), suggesting that these strains carry only one mutation. It is likely, therefore, that the spontaneously aroused petite strains are responding normally to the reduced level of fermentable carbon in repressing fermentation. Unlike the respiratory-competent cells however, they cannot produce ATP by respiration and have to enter stationary phase rapidly to survive. The low ATP level may be involved in the signaling process, in part because it is the precursor of cAMP (see introductory section). Unlike stationaryphase-defective mutants (see introductory section), petite strains do not lose viability within at least 10 days in YPDA medium and show a low percentage of budded cells in the stationary phase. In this paper it is shown that total mRNAs, as well as a few examples of individual mRNAs, decrease more dramatically and within a much shorter period of time in the petite strain relative to the respiratory-competent strains. For example, the ratio between total mRNA level in log phase and its level 2 days after cells enter stationary phase is 2.7 in the respiratory-competent cells and 35 in the petite cells.

The stationary phase is a dynamic rather than a static phase. Cell physiology at the beginning of this phase is different from that in the late stationary phase. For example, when stationary-phase cells are shifted back to optimal conditions, the onset of budding is observed after a specific delay. The length of the delay is positively correlated with the time the cells have been arrested in stationary phase (Iida and Yahara 1984a). The mRNA levels of HSP26 and SSA3, which are gradually reduced during prolonged incubation in the stationary phase (Figs. 1B and 4C), is another example of dynamic gene expression during the stationary phase. Petite strains are a more convenient model system than respiratory-competent strains for studying stationary-phase dynamics because of the faster kinetics with which changes occur in these strains.

The mechanism by which topoisomerase I functions in the general transcriptional repression remains to be determined. The general nature of the phenomenon suggests that it acts on a common denominator of the majority of genes. One possible common denominator may be found in chromatin architecture. Chromatin structure, in general, is suggested to be inhibitory for transcription (for review, see Wolffe 1990). A non-nucleosomal region, found at the promoters of many transcriptionally active genes, is necessary for efficient transcription (Wolffe 1990). Assembly of nucleosomes or a higher-order structure is likely to require topo- isomerase activity needed to relax the positive supercoils accumulated between nucleosomes (Germond et al. 1975) or those resulting from a higher-order structure formation. Thus, it is suggested that following the diauxic shift, topoisomerase I is involved in changing chromatin structure which, in turn, results in the transcriptional repression. Topoisomerase II, which is inefficient in DNA relaxation in vivo (Wang 1991), probably plays only a marginal role in this process. Alternatively, topoisomerase I can only indirectly affect the repression of most genes by interfering somehow (transcriptionally or post-transcriptionally) with factor(s) involved in the actual repression mechanism. Further experiments to explore these possibilities are under way.

The stationary phase, or analogous physiological conditions, have been an important, if not the primary, stage for natural selection during the evolution of unicellular organisms. This is based on the assumption that in nature unicellular organisms exist largely under these conditions. One of the most fundamental and interesting questions that yeast genetics has raised is why so many genes seem to be dispensable for viability and why disruption of a subset of these genes does not lead to a more severe phenotype. I suggest that some of these genes play a major role in the stationary phase, a phase which, in yeast, has been little investigated.

\section{Materials and methods}

Yeast strains, culture, plasmids, and cDNA library

SD116, SD117, SD118, and SD119 were described by Brill et al. (1987). CH325 was described by Holm et al. (1985). JCW7 (MAT $\alpha$, ade2-101, Leu2-d1, lys2-801, trp1-d1, ura3-52, $\triangle$ top1::URA3) and JCW8 (MAT $\alpha$, ade2-101, Leu2-dl, lys2-801, trp1-d1, ura3-52, top2-4, $\Delta$ top1::URA3) were derived from JCW5 (MAT $\alpha$, ade2-101, Leu2-d1, lys2-801, trp1-d1, ura3-52, $\mathrm{TOP}^{+}$) and JCW6 (MAT $\alpha$, ade2-101, Leu2-d1, lys2-801, trp1-d1, ura3-52, top2-4), respectively, by replacing a large fragment of TOP1 with URA3 (R. Kim and J.C. Wang, unpubl.). CH325p and CH325p1 are respiratory-defective (petite) strains spontaneously derived from $\mathrm{CH} 325$ by screening for petite colonies in $1 \%$ Bacto-yeast extract, $2 \%$ Bacto-peptone (rich) plate supplemented with $3 \%$ glycerol and $0.1 \%$ dextrose (Sherman et al. 1986). $\mathrm{MCl}$ strains were derived from $\mathrm{CH} 325$ p by replacing a large fragment of TOP1 with URA3, using a procedure described previously (Rothstein 1983; Goto and Wang 1985).

Cells were grown at $25^{\circ} \mathrm{C}$ in a low-phosphate medium (YEPPi) containing $2 \%$ galactose or, where indicated, $2 \%$ dextrose (Rubin 1975). In some cases, cells were grown in rich medium containing $2 \%$ dextrose, supplemented with $720 \mu \mathrm{g} / \mathrm{ml}$ of adenine (YPDA). Cells were grown for many generations in the log phase before final inoculation at the beginning of an experiment.

SSA3 plasmid was generously provided by E.A. Craig (Boorstein and Craig 1990b). HSP26 plasmid was generously provided by S. Lindguist (Petko and Lindquist 1986). Yeast cDNA library in $\lambda$ gt 10 was a generous gift of R.A. Young (Huynh et al. 1985).

\section{RNA extraction and analyses}

Comparable amounts of cells $\left(5-10 \mathrm{OD}_{600}\right.$ equivalents) were collected by centrifugation, washed with water, resuspended in $400 \mu \mathrm{l}$ of ice-cold extraction buffer $[0.2 \mathrm{M}$ Tris- $\mathrm{HCl}$ at $\mathrm{pH} 7.5,0.5$ 
$\mathrm{M} \mathrm{NaCl}, 10 \mathrm{~mm}$ EDTA, $0.1 \%$ diethylpyrocarbonate (Finley et al. 1989|], in a screw-capped Eppendorf tube, and stored immediately at $-75^{\circ} \mathrm{C}$. When all samples were collected, $400 \mu l$ of glass beads and $400 \mu \mathrm{l}$ of phenol-chloroform (1:1 vol/vol) was added while the cell suspensions were still frozen and kept on ice. All tubes were vortexed together, by using a multiple sample head (VWR) at the highest speed for $2.5 \mathrm{~min}$ at room temperature (it takes from 10 to $20 \mathrm{sec}$ of vortexing for the frozen suspension to thaw). Samples were centrifuged at $4^{\circ} \mathrm{C}$ for $8 \mathrm{~min}$, and the aqueous phases were extracted with phenol-chloroform $(1: 1 \mathrm{vol} /$ vol) and ethanol-precipitated. RNA pellets were dissolved in 40 $\mu \mathrm{l}$ of $\mathrm{H}_{2} \mathrm{O}$, and RNA concentrations were measured by $\mathrm{OD}_{260}$.

Electrophoresis was done as described (Finley et al. 1989). RNA was blotted onto a GeneScreen filter and hybridized as described (Church and Gilbert 1984). Filters were washed at $65^{\circ} \mathrm{C}$ for $20 \mathrm{~min}$ with $5 \%$ SDS, $40 \mathrm{~mm} \mathrm{Na-phosphate}(\mathrm{pH} 7.2)$, and $1 \mathrm{~mm}$ EDTA, followed by $1 \mathrm{hr}$ of three washes at $65^{\circ} \mathrm{C}$ with $1 \%$ SDS, $40 \mathrm{~mm}$ Na-phosphate $(\mathrm{pH} 7.2)$, and $1 \mathrm{~mm}$ EDTA.

To determine total mRNA level, 1-2 $\mu \mathrm{g}$ of heat-denatured RNA $\left(70^{\circ} \mathrm{C}\right.$ for $3 \mathrm{~min}$ ) was added to $100 \mu \mathrm{l}$ of $1 \mathrm{~m}$ ammonium acetate and blotted onto a nitrocellulose filter (BA 85, Schleicher \& Schuell) with a dot blotter minifold (Schleicher \& Schuell). The filter was air-dried and baked at $80^{\circ} \mathrm{C}$, under vacuum, for $45 \mathrm{~min}$. The filter was then prehybridized overnight at $37^{\circ} \mathrm{C}$ in $4 \times \mathrm{SSC}(1 \times \mathrm{SSC}$ is $0.15 \mathrm{M} \mathrm{NaCl}, 0.015 \mathrm{Na}$-citrate $), 0.2 \%$ Ficoll, $0.2 \%$ polyvinylpyrrolidone, $0.5 \%$ SDS, and $200 \mu \mathrm{g} / \mathrm{ml}$ of denatured salmon sperm DNA, followed by hybridization at $37^{\circ} \mathrm{C}$ with $8 \mu \mathrm{Ci} / \mathrm{ml}$ of ${ }^{32} \mathrm{P}$-labeled poly[d(T)] in the prehybridization buffer for $12-20 \mathrm{hr}$. The filter was washed at $37^{\circ} \mathrm{C}$ with the prehybridization buffer for $15 \mathrm{~min}$, followed by $1 \mathrm{hr}$ of three washes at room temperature in $1 \times$ SSC and $0.1 \%$ SDS.

\section{Preparation of probes}

Yeast cDNA insert in $\lambda g t 10$ was amplified by polymerase chain reaction (PCR) from a single plaque DNA (collected and introduced into the reaction tube by a toothpick) with primers of vector sequences near the vector/insert junction of the following sequences: 5'-GGGGGTAAATAACAGAGGTGGCTT-3' and 5 '-CCTTTTGAGCAAGTTCAGCCTGGT- 3 '. The reaction was carried out in $25 \mathrm{~mm} \mathrm{KCl}, 1.5 \mathrm{mM} \mathrm{MgCl}_{2}, 20 \mathrm{~mm}$ Tris- $\mathrm{HCl}$ (pH 8.3 ), $0.1 \mathrm{mg} / \mathrm{ml}$ of gelatin, $0.2 \mathrm{mM}$ of each dNTP, $0.5 \mu \mathrm{M}$ of each primer, and $26 \mathrm{U} / \mathrm{ml}$ of Taq DNA polymerase (BRL). Thirty amplification cycles of $40 \mathrm{sec}$ at $95^{\circ} \mathrm{C}, 1 \mathrm{~min}$ at $55^{\circ} \mathrm{C}$, and $2 \mathrm{~min}$ at $73^{\circ} \mathrm{C}$ were done. The amplified insert was gel-purified and labeled by three to nine PCR amplification cycles essentially as described above except that $\left[\alpha^{-32} \mathrm{P}\right] \mathrm{dGTP}$ at $1 \mathrm{mCi} / \mathrm{ml} / 400 \mathrm{Ci} /$ mmole) was used instead of the dGTP, the concentrations of each of the unlabeled dNTPs were $20 \mu \mathrm{M}$, and the extension time was $7 \mathrm{~min}$. Unincorporated nucleotides were removed before hybridization by ethanol precipitation in the presence of $3.75 \mathrm{M}$ ammonium acetate.

Radiolabeled poly $[\mathrm{d}(\mathrm{T})]$ was obtained by reverse transcription in the following way: A 10- $\mu$ l reaction contained $50 \mathrm{ng}$ of poly[r(A)], $2.4 \mu \mathrm{g} / \mathrm{ml}$ of oligo [d(T) $\left.)_{12-18}\right], 50 \mathrm{mM}$ Tris- $\mathrm{HCl}(\mathrm{pH}$ $8.3 \mid, 75 \mathrm{mM} \mathrm{KCl}, 3 \mathrm{~mm} \mathrm{MgCl} 2,10 \mathrm{mM} \mathrm{DTT}, 10 \mu \mathrm{Ci}\left[\alpha^{-}{ }^{32} \mathrm{P}\right] \mathrm{dTTP}$ $(400 \mathrm{Ci} / \mathrm{mmole})$, and 50 units of Moloney murine leukemia virus (MMLV) reverse transcriptase (BRL) and was carried out at $37^{\circ} \mathrm{C}$ for $1 \mathrm{hr}$. To terminate the reaction, the sample was brought to $0.2 \mathrm{M} \mathrm{NaOH}, 0.1 \% \mathrm{SDS}$, in $70 \mu \mathrm{l}$ and incubated at $70^{\circ} \mathrm{C}$ for $10 \mathrm{~min}$. Carrier DNA was added, and the sample was neutralized by the addition of $15 \mu \mathrm{l}$ of $0.7 \mathrm{M} \mathrm{HCl}, 1 \mathrm{M}$ Trisma base, and $90 \mu \mathrm{l}$ of $7.5 \mathrm{M}$ ammonium acetate followed by ethanol precipitation.

Radiolabeled cDNA $\left(10^{8}-10^{9} \mathrm{cpm} / \mu \mathrm{g}\right)$ was prepared by reverse transcription as follows: A $10-\mu 1$ reaction containing $1-2$ $\mu \mathrm{g}$ of mRNA was reversetranscribed in $50 \mathrm{mM}$ Tris- $\mathrm{HCl} / \mathrm{pH}$ 8.3), $75 \mathrm{~mm} \mathrm{KCl}, 10 \mathrm{~mm} \mathrm{DTT}, 3 \mathrm{mM} \mathrm{MgCl}, 80 \mu \mathrm{g} / \mathrm{ml}$ of oli$\operatorname{go}\left[\mathrm{d}\left(\mathrm{T}_{12-18}\right)\right], 0.5 \mathrm{~mm}$ each of dATP, dCTP, and dTTP, $15 \mu \mathrm{Ci}$ $\left[\alpha^{-32} \mathrm{P}\right] \mathrm{dGTP}(400 \mathrm{Ci} / \mathrm{mmole})$, and 50 units of MMLV reverse transcriptase. The reaction was carried out at $37^{\circ} \mathrm{C}$ for $1 \mathrm{hr}$ and terminated as described for the preparation of poly[d(T)] probe (see above).

\section{In vivo labeling of cells}

Labeling was done essentially as described (Rubin 1975). Briefly, cells were grown in low phosphate-rich medium. ${ }^{32} \mathrm{PO}_{4}$ was added to the medium to a final concentration of $0.5 \mathrm{mCi} / \mathrm{ml}$, and labeling was carried out at $25^{\circ} \mathrm{C}$ for $6-10 \mathrm{~min}$. Cells were spun for $10 \mathrm{sec}$ in an Eppendorf centrifuge, washed with ice-cold $\mathrm{H}_{2} \mathrm{O}$, and resuspended in ice-cold RNA extraction buffer as described above and stored immediately at $-75^{\circ} \mathrm{C}$.

\section{Preparation of plaque filter replicas and hybridization} of filters with labeled cDNA

Multiple filter replicas were prepared as described previously (St. John and Davis 1979). Filters were prehybridized in plastic bags in $50 \%(\mathrm{vol} / \mathrm{vol})$ formamide, $5 \times \mathrm{SSC}, 0.5 \%$ SDS, $0.2 \%$ Ficoll, $0.2 \%$ polyvinylpyrrolidone, $10 \mu \mathrm{g} / \mathrm{ml}$ of poly(A), and 100 $\mu \mathrm{g} / \mathrm{ml}$ of denatured salmon sperm DNA at $42^{\circ} \mathrm{C}$ for $12 \mathrm{hr} .{ }^{32} \mathrm{P}-$ Labeled cDNA $(625,000 \mathrm{cpm} / \mathrm{ml})$ was then added, and hybridization was carried out at $42^{\circ} \mathrm{C}$ for $40 \mathrm{hr}$. Filters were washed in $40 \mathrm{~mm} \mathrm{Na}$-phosphate ( $\mathrm{pH} 7.2), 1 \%$ SDS, and $1 \mathrm{mM}$ EDTA for 5 $\mathrm{min}$ at room temperature, $25 \mathrm{~min}$ at room temperature, and 70 min of two washes at $67^{\circ} \mathrm{C}$.

\section{Acknowledgments}

I thank James C. Wang and Richard A. Young for research support, laboratory facilities and advice. I am grateful to Gerald Fink, Linda Hyman, Peter Murray, Nava Segev, and Alexander Varshavsky for critically reading the manuscript and to Elizabet Craig, Connie Holm, Susan Lindquist, and Rolf Sternglanz for sending me yeast strains and plasmids. The bulk of this work has been carried out at the laboratory of James C. Wang and part of it at the laboratory of Richard A. Young.

The publication costs of this article were defrayed in part by payment of page charges. This article must therefore be hereby marked "advertisement" in accordance with 18 USC section 1734 solely to indicate this fact.

\section{References}

Aves, S.J., B.W. Durkacz, A. Carr, and P. Nurse. 1985. Cloning, sequencing and transcriptional control of the Schizosaccharomyces pombe cdc10 "start" gene. EMBO I. 4: 457-463.

Boorstein, W.R. and E.A. Craig. 1990a. Regulation of a yeast HSP70 gene by a cAMP responsive transcriptional control element. $E M B O /$. 9: 2543-2453.

- 1990b. Transcriptional regulation of SSA3, an HSP70 gene from Saccharomyces cerevisiae. Mol. Cell. Biol. 10: $3262-3267$.

Boucherie, H. 1985. Protein synthesis during transition and stationary phases under glucose limitation in Saccharomyces cerevisiae. J. Bacteriol. 161: 385-392.

Breviario, D., A.G. Hinnebusch, and R. Dhar. 1988. Multiple regulatory mechanisms control the expression of the RAS1 and RAS2 genes of Saccharomyces cerevisiae. EMBO $/$. 7: 1805-1813. 
Brill, S.J. and R. Sternglanz. 1988. Transcription-dependent DNA supercoiling in yeast DNA topoisomerase mutants. Cell 54: 403-411.

Brill, S.J., S. DiNardo, M.K. Voelkel, and R. Sternglanz, R. 1987. Need for DNA topoisomerase activity as a swivel for DNA replication and for transcription of ribosomal RNA. Nature 326: 414-416 (published erratum appears on p. 812).

Cannon, J.F. and K. Tatchell. 1987. Characterization of Saccharomyces cerevisiae genes encoding subunits of cyclic AMPdependent protein kinase. Mol. Cell. Biol. 7: 2653-2663.

Church, G.M. and W. Gilbert. 1984. Genomic sequencing. Proc. Natl. Acad. Sci. 81: 1991-1995.

Drebot, M.A., G.C. Johnston, and R.A. Singer. 1987. A yeast mutant conditionally defective only for reentry into the mitotic cell cycle from stationary phase. Proc. Natl. Acad. Sci. 84: 7948-7952.

Drebot, M.A., D.L. Veinot, R.A. Singer, and G.C. Johnston. 1990. Induction of yeast histone genes by stimulation of stationary phase cells. Mol. Cell. Biol. 10: 6356-6361.

Durkacz, B., A. Carr, and P. Nurse. 1986. Transcription of the cdc2 cell cycle control gene of the fission yeast Schizosaccharomyces pombe. EMBO I. 5: 369-373.

Entian, K.D. 1986. Glucose repression: A complex regulation system in yeast. Microbiol. Sci. 3: 366-371.

Finley, D., E. Ozkaynak, and A. Varshavsky. 1987. The yeast polyubiquitin gene is essential for resistance to high temperatures, starvation, and other stresses. Cell 48: 1035-1046.

Finley, D., B. Bartel, and A. Varshavsky. 1989. The tails of ubiquitin precursors are ribosomal proteins whose fusion to ubiquitin facilitates ribosome biogenesis. Nature 338: 394-401.

Germond, J.E., B. Hirt, M. Gross-Bellard, and P. Chambon. 1975. Folding of the DNA double helix in chromatin-like structures from Simian Virus 40. Proc. Natl. Acad. Sci. 72: $1843-1847$.

Goto, T. and J.C. Wang. 1984. Yeast DNA topoisomerase II is encoded by a single-copy, essential gene. Cell 36: 10731080.

- 1985. Cloning of yeast TOP1, the gene encoding DNA topoisomerase $\mathrm{I}$, and construction of mutants defective in both DNA topoisomerase I and DNA topoisomerase II. Proc. Natl. Acad. Sci. 82: 7178-7182.

Holm, C, T. Goto, J.C. Wang, and D. Botstein. 1985. DNA topoisomerase II is required at the time of mitosis in yeast. Cell 41: $553-563$.

Huynh, T.V., R.A. Young, and R.W. Davis. 1985. Constructing and screening cDNA libraries in $\lambda \mathrm{gt} 10$ and $\lambda \mathrm{gtl} l \mathrm{l}$. In DNA cloning: A practical approach, Vol l. (ed. D.M. Glover), pp. 49-78. IRL Press, Oxford.

Iida, H. and I. Yahara. 1984a. Durable synthesis of high molecular weight heat shock proteins in Go cells of the yeast and other eucaryotes. I. Cell. Biol. 99: 199-207.

—. 1984b. Specific early-G1 blocks accompanied with stringent response in Saccharomyces cerevisiae lead to growth arrest in resting state similar to the Go of higher eucaryotes. J. Cell. Biol. 98: 1185-1193.

Kappeli, O. 1986. Regulation of carbon metabolism in Saccharomyces cerevisiae and related yeasts. $A d v$. Microb. Physiol. 28: 181-209.

Kim, R.A. and J.C. Wang. 1989. A subthreshold level of DNA topoisomerases leads to the excision of yeast rDNA as extrachromosomal rings. Cell 57: 975-985.

Lagunas, R. 1986. Misconceptions about the energy metabolism of Saccharomyces cerevisiae. Yeast 2: 221-228.

Matsumoto, K., I. Uno, Y. Oshima, and T. Ishikawa. 1982. Isolation and characterization of yeast mutants deficient in adenylate cyclase and cAMP-dependent protein kinase. Proc.
Natl. Acad. Sci. 79: 2355-2359.

Matsumoto, K., I. Uno, and T. Ishikawa. 1983. Control of cell division in Saccharomyces cerevisiae mutants defective in adenylate cyclase and cAMP-dependent protein kinase. Exp. Cell. Res. 146: 151-161.

Paris, S. and J.R. Pringle. 1983. Saccharomyces cerevisiae: Heat and gluculase sensitivities of starved cells. Ann. Microbiol. 134: 379-385.

Petko, L. and S. Lindquist. 1986. HSP26 is not required for growth at high temperatures, nor for thermotolerance, spore development, or germination. Cell 45: 885-894.

Plesset, J., J.R. Ludwig, B.S. Cox, and C.S. McLaughlin. 1987. Effect of cell cycle position on thermotolerance in Saccharomyces cerevisiae. J. Bacteriol. 169: 779-784.

Praekelt, U.M. and P.A. Meacock. 1990. HSP12, a new small heat shock gene of Saccharomyces cerevisiae: analysis of structure, regulation and function. Mol. Gen. Genet. 223: 97-106.

Pringle, J. and L. Hartwell. 1981. The Saccharomyces cerevisiae cell cycle. In The molecular biology of the yeast Saccharomyces: Life cycle and inheritance (ed. J.N. Strathern, E.W. Jones, and J.R. Broach), pp. 97-142. Cold Spring Harbor Laboratory, Cold Spring Harbor, New York.

Rose, D., W. Thomas, and C. Holm. 1990. Segregation of recombined chromosomes in meiosis I requires DNA topoisomerase II. Cell 60: 1009-1017.

Rothstein, R.J. 1983. One-step gene disruption in yeast. Methods Enzymol. 101: 202-211.

Rubin, G.M. 1975. Preparation of RNA and ribosomes from yeast. Methods Cell Biol. 12: 45-64.

St. John, T.P. and R.W. Davis. 1979. Isolation of galactose-inducible DNA sequences from Saccharomyces cerevisiae by differential plaque filter hybridization. Cell 16: 443-452.

Seufert, W. and S. Jentsch. 1990. Ubiquitin-conjugating enzymes UBC4 and UBC5 mediate selective degradation of short-lived and abnormal proteins. EMBO I. 9: 543-550.

Sherman, F., G.R. Fink, and J.B. Hicks. 1986. Methods in yeast genetics. Cold Spring Harbor Laboratory, Cold Spring Harbor, New York.

Thrash, C., A.T. Bankier, B.G. Barrell, and R. Sternglanz. 1985. Cloning, characterization, and sequence of the yeast DNA topoisomerase I gene. Proc. Natl. Acad. Sci. 82: 4374-4378.

Toda, T., S. Cameron, P. Sass, M. Zoller, J.D. Scott, B. McMullen, M. Hurwitz, E.G. Krebs, and M. Wigler. 1987. Cloning and characterization of BCY1, a locus encoding a regulatory subunit of the cyclic AMP-dependent protein kinase in Saccharomyces cerevisiae. Mol. Cell. Biol. 7: 1371-1377.

Toda, T., I. Uno, T. Ishikawa, S. Powers, T. Kataoka, D. Broek, S. Cameron, J. Broach, K. Matsumoto, and M. Wigler. 1985. In yeast, RAS proteins are controlling elements of adenylate cyclase. Cell 40: 27-36.

Wallis, J.W., G. Chrebet, G. Brodsky, M. Rolfe, and R. Rothstein. 1989. A hyper-recombination mutation in S. cerevisiae identifies a novel eukaryotic topoisomerase. Cell 58: 409-419.

Wang, J.C. 1991. DNA topoisomerases: Why so many? J. Biol. Chem. 266: 6659-6662.

Werner, W.M., J. Becker, S.J. Kosic, and E.A. Craig. 1989. Yeast HSP70 RNA levels vary in response to the physiological status of the cell. J. Bacteriol. 171: 2680-2688.

Wolffe, A.P. 1990. New approaches to chromatin function. New Biologist 2: 211-218. 


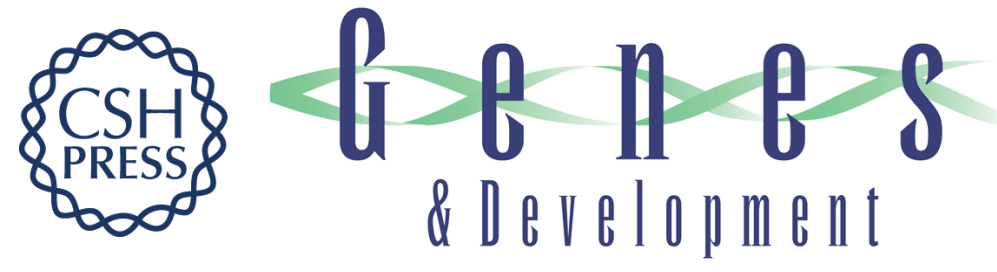

\section{A general topoisomerase l-dependent transcriptional repression in the stationary phase in yeast.}

M Choder

Genes Dev. 1991, 5:

Access the most recent version at doi:10.1101/gad.5.12a.2315

References This article cites 42 articles, 16 of which can be accessed free at:

http://genesdev.cshlp.org/content/5/12a/2315.full.html\#ref-list-1

License

Email Alerting

Service

Receive free email alerts when new articles cite this article - sign up in the box at the top right corner of the article or click here.

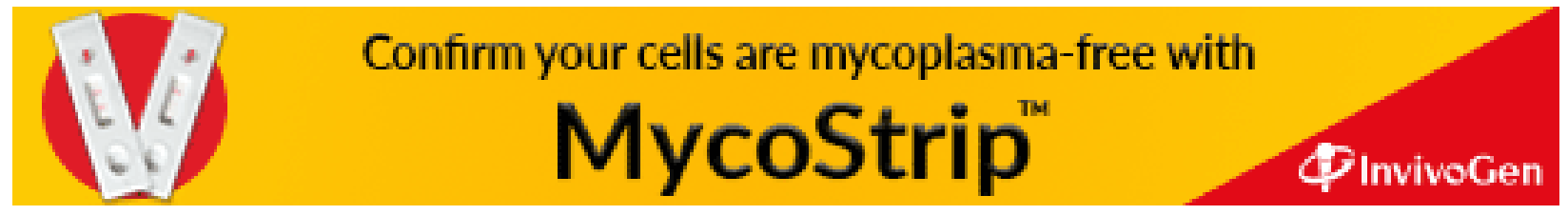

